\title{
BREVE NOTA SOBRE A POESIA DE ODORICO MENDES
}

\author{
José Quintão de Oliveira
}

Manuel Odorico Mendes, ilustrado tradutor dos clássicos latinos e gregos, tem sido ao longo do tempo (e principalmente nos últimos anos) bastante discutido. Normalmente esse interesse tem sido provocado pelas suas traduções que, depois de várias edições, com uma fortuna crítica e uma circulação maior que a de muitos poetas e prosadores destacados, quase se pode dizer, estão hoje incorporadas ao cânone literário nacional. Não se trata porém de uma ocorrência isolada. Inúmeras traduções têm sobrevivido à sua época e continuam a ser publicadas ao longo do tempo, como ocorre com aquelas da lavra de Machado de Assis, tanto na prosa como na poesia; com a tradução d'A Divina comédia por José Pedro Xavier Pinheiro, praticamente não discutida pela crítica da atualidade e, tudo indica, mais editada que as de Odorico. Também não é um movimento restrito ao nosso país como pode muito bem se constatar no caso da tradução do Rubáiyát de Omar Kháyyám por Edward Fitzgerald, que atrai leitores e estudiosos não só de língua inglesa. Aliás, essa tradução foi por sua vez traduzida ao português por Jamil Almansur Haddad (Rio de Janeiro: Civilização Brasileira, 1964) e está presente também na festejada versão dos poemas de Kháyyám feita por Otávio Tarquínio de Souza, além de outras. Aparentemente a partir do século 19 ocorre um movimento espontâneo de valorização da tradução, nesse movimento se inscrevendo o curso do trabalho de Odorico Mendes. 
Esse tradutor, importante político da primeira metade do século 19, foi também poeta, deixando espalhados em periódicos e opúsculos da época alguns poemas e ainda alguns poucos inéditos, publicados depois da sua morte. Além dessa pequena produção, os também maranhenses Henriques Leal e João Francisco Lisboa mencionam um bauzinho que teria sido furtado ao poeta durante uma viagem, quando passava pela Bahia. Esse objeto conteria toda sua produção não publicada e nunca foi recuperado. A partir desse acontecimento Odorico parece ter renunciado ao poetar autônomo para se dedicar com exclusividade à atividade política. A tradução dos clássicos foi uma tarefa a que se dedicou tardiamente, depois de se afastar da atividade político-partidária, vindo a morrer antes de ver estampada em letra de forma a totalidade do seu trabalho. Sua versão da Odisseia só foi impressa em 1928, mais de sessenta anos depois da morte do autor, em pleno Modernismo. Odorico deixou também um opúsculo em que estabelece com bastante erudição a autoria portuguesa do Palmerim de Inglaterra, publicado em 1860. Dessa última obra, da pequena correspondência e de algum outro escrito em prosa, tal como do trabalho do tradutor não se falará nestas notas; interessa aqui o poeta. Conhecer essa poesia pode ser um caminho auxiliar para melhor conhecer o tradutor e o pensador da tradução.

Odorico Mendes nasceu em São Luís, no Maranhão, em 1799 e morreu, durante uma viagem de trem, em Londres, em 1864 e lá foi sepultado. Foi personalidade de destaque como político ativo no período que medeia do primeiro ao segundo reinado, atravessando a transitoriedade das regências. Mais tarde, afastado da política ativa deu-se às musas clássicas traduzindo Homero e Virgílio. Henriques Leal data dos treze anos de idade a sua mais antiga produção poética - um soneto motivado pelo supliciamento de um escravo. Do período de estudante em Coimbra, segundo informa Wolf (1863), data seu poema mais conhecido o hino (ou ode) À tarde. Além desses, há ainda mais dois poemas que costumam ser especialmente lembrados, intitulados $\mathrm{O}$ meu retiro e $\mathrm{O}$ sonho (ou $\mathrm{A}$ morte, como às vezes aparece nomeado). Posteriormente, até a maturidade, publicou mais alguns versos, sempre de circunstância. Assim, tudo indica que a partir do desaparecimento dos seus originais juntamente com o bauzinho que os continha, Odorico renunciou mesmo ao poetar autônomo, só voltando à poesia para se entregar com exclusividade à tradução dos grandes.

A coletânea que segue esta nota poderia ser talvez intitulada "poesia completa" deManuelOdoricoMendes, umavezquerecolheaparentemente tudo o que se conhece do que produziu de estro próprio. Como já foi dito 
e é do geral conhecimento, o que garantiu sua entrada nos compêndios de história da nossa literatura foi a sua condição de tradutor, tendo vertido ao português os autores clássicos Homero e Virgílio. Traduziu ainda um escritor mais próximo, Voltaire, de quem trouxe à língua portuguesa as tragédias Mérope (1831) e Tancredo (1939). Seu trabalho foi à época bastante valorizado pela maioria dos seus confrades da intelectualidade maranhense, grupo de que poderia ser dito o decano. Encontrou também ao longo da sua trajetória forte oposição em críticos como Silvio Romero, Frederico José Corrêa e, mais recentemente, Antonio Candido, na sua Formação da literatura brasileira. Nos últimos anos, alguns críticos especialmente a partir dos concretistas - tentam recuperar e valorizar o seu empreendimento tradutório, destacando-lhe o pioneirismo e a reflexão sobre a arte da tradução, como é o caso de Haroldo de Campos (1992).

Os poemas da lavra do maranhense são os seguintes: À tarde, O sonho, O meu retiro, A um preso, À S. M. o Sr. D. Pedro II no dia 2 de dezembro de 1839, "Despido em praça pública, amarrado", "Sai Minotauro com feroz bramido", "Sempre a teu mando pronto obedecendo", "Partis, adeus amigo, adeus, senhora", "Vejo-te, não me ilude a fantasia"; o chamado Trio da guerra da Itália, formado pelos sonetos intitulados Luís Napoleão, Vitório Emanuel e Garibaldi. Por último aparece o epitáfio para a mulher e filhos de um amigo, que começa pelo verso "Aqui, junto da mãe, cortada em flor". Observe-se que os títulos entre aspas se referem a poemas publicados sem título e por isso identificados pelo primeiro verso. Alguns dos cinco poemas iniciais são mais longos, todos poderiam ser ditos odes, são seguidos por oito sonetos e o epitáfio, totalizando 14 peças, em resumo.

A ode que abre a antologia que segue - À tarde -, às vezes dito Hino à tarde, é o mais conhecido dos poemas de Odorico Mendes. Sílvio Romero diz que "nunca o pude ler sem boa e saudosa emoção." (1953. p. 794) São versos "onde circula um não sei quê de vago e doce, que bem parece a essência mesma da poesia.” (p. 794) Para José Veríssimo, "mesclam-se nesta composição o clássico e o romântico, uma inspiração ainda arcádica e européia e sentimentos brasileiros e estilo moderno." (1963. p. 189) Para este crítico, o poema de Odorico é do que de melhor se produziu no seu tempo e "prenuncia Gonçalves Dias pelo tom sentimental do seu lirismo mais subjetivo que o de [Gonçalves de] Magalhães." (p. 189) O prenúncio a Gonçalves Dias talvez possa ser apontado pela vinculação do poema à tópica do canto do exilado.

A primeira impressão desse poema data de 1832, quando circulou em opúsculo preparado pelo impressor Inácio Pereira da Costa, dito Papeleta, da Tipografia Americana, conforme informado por Henriques Leal. Excetuada essa, não encontrada, compulsaram-se diversas versões 
do poema para se definir aquela que seria aqui utilizada. Devem ser destacadas aquela de Wolf (1863) e do próprio Leal (1873), que publica pelo menos dois fragmentos do poema e uma versão integral; a Castália brasileira de Olinto Meira (1850) e o Parnaso de Pereira da Silva (18431848). Consultou-se também o Curso de literatura brasileira de Melo Morais Filho, em que aparece com o título de A tarde (1902. p. 399-402); com o mesmo título já fora incluído por esse antologista no seu Parnaso brazileiro (1885. p. 437-440). Mencione-se ainda o Parnaso maranhense, de Almeida Braga e outros (1861. p. 210-214) e, finalmente, a Minerva Brasiliense (1844). Esta última parece ser a melhor delas, uma vez que Odorico Mendes era colaborador da revista, o que faz supor ter ele mesmo entregado o poema para publicação. Em consequência poderia ser a última publicação em vida do autor em que parece ter ocorrido a sua participação. Não se sabe a origem da versão de Wolf, que traz erros evidentes e certamente não a terá recebido de Odorico. Também em Henriques Leal são evidentes os erros, restando a versão da Minerva como a mais confiável também por esse critério. Igualmente Sílvio Romero preferiu esta versão, que inclui com pequenas alterações na sua História da literatura brasileira (1953), embora sem apontar as razões da escolha.

O Parnaso maranhense reproduz três poemas de Odorico; o primeiro deles esse À tarde; o segundo, A morte e ainda o soneto "Sempre a teu mando pronto obedecendo". Essa publicação saiu em 1861, portanto em vida do autor. Apesar disso, não parece uma boa fonte. Odorico à época vivia na Europa (para onde se deslocara em 1847), dedicado à tradução de Homero e à publicação das traduções de Virgílio, dificilmente teria revisto os poemas para enviá-los aos organizadores da publicação. $\mathrm{O}$ mais provável é que os versos que publicaram tenham sido obtidos mesmo no Maranhão ou em alguma publicação avulsa, não parecendo despropósito imaginar que poderiam ter sido mesmo resultado do trabalho da memória de algum dos envolvidos na empreitada. Nesse livro o poema À tarde, entre outras divergências traz dois versos a menos que a versão da Minerva: "Ali também no ouvido lhe estremecem / De mãe, de amigo os maviosos nomes". Nada indica que essa subtração tal como as demais divergências encontradas possam ser atribuída a uma revisão autoral. Aliás, deve-se anotar que a mesma lacuna ocorre na edição de Pereira da Silva, entre outras coincidências, o que talvez indique ser essa a fonte da publicação maranhense. Assim, parece se tratar mesmo de um erro; mais um índice favorável à escolha da versão acolhida pela Minerva. Nessa versão ocorrem duas quebras de pé de página, que, no entanto, não geram confusão quanto à divisão das estrofes. Affeito, no oitavo verso foi transcrito como afeto. O verso "Do rio que espontâneo se oferece" traz, 
no original, depois da palavra "rio" um sinal gráfico que a qualidade do material não permite precisar. Trata-se definitivamente de uma vírgula; sobre essa há uma marca que não é possível distinguir completamente, podendo ser um ponto irregular, que faria ponto e vírgula ou uma simples mancha de tinta. Por analogia com os versos seguintes, eliminouse a pontuação, seguindo a lição de Sílvio Romero na sua História da literatura brasileira. Essa é a única intervenção sobre a pontuação original. Registra-se ainda que esse poema (parcialmente) e $\mathrm{O}$ sonho (integralmente) estão reproduzidos no livro de Haroldo Paranhos (1937).

O segundo volume da antologia de Pereira da Silva ${ }^{1}$ recolhe cinco poemas de Odorico: À tarde, O meu retiro; dois poemas identificados como Odes I e II, tendo o primeiro deles o título de A um preso, o segundo é A morte (O sonho), e o soneto "Sempre a teu mando pronto obedecendo". Desses apenas o quarto poema, identificado como Ode II: A um preso, não está também reproduzido no livro de Henriques Leal.

Os demais poemas são reproduzidos do primeiro volume do Pantheon maranhense, sendo que para alguns deles essa é a única fonte até agora disponível. Esse livro traz um apêndice intitulado Notas (v. I. p. 277-287), que reúne três poemas da lavra de Odorico Mendes: Á tarde (com o título de Hino à tarde), $\mathrm{O}$ sonho e $\mathrm{O}$ meu retiro. Ao longo do texto dedicado ao poeta transcreve vários outros além de fragmentos dos três acima citados. Essa obra registra equivocadamente que o poema $\mathrm{O}$ meu retiro foi recolhido às páginas da Minerva Brasiliense. Antônio Medina Rodrigues (2000) incorre no mesmo erro. Na realidade, o único poema de Odorico que ali apareceu foi o já referido "À tarde", como na falta da revista se pode confirmar nos índices da Minerva publicados por Hélio Lopes (1978). O livro de Henriques Leal teve uma segunda edição mais recente (Rio de Janeiro: Alhambra, 1987) que agrava os erros na reprodução dos poemas já existentes na primeira. Apesar de todos esses problemas, é sempre bom lembrar que Antônio Henriques Leal foi o guardião dos papéis de Odorico Mendes resgatados pelo poeta Gonçalves Dias em Londres depois da morte do tradutor. Portanto, com todas as dificuldades apontadas, é quase sempre a melhor (quando não única) fonte disponível.

$\mathrm{O}$ quarto verso do poema $\mathrm{O}$ meu retiro - "Egrégios torreões, alvos da inveja" - no original traz o termo "alvo" no sigular, a aparente gralha tipográfica foi corrigida. Já o "a" do verso "Se entra-lhe a casa a mísera desdita” desse mesmo poema aparece com acento agudo

1 Livro alcançado graças às pesquisas de José Américo Miranda, a quem se cnsigna o devido crédito 
no original. Deve-se observar que não se trata de erro de escrita substituindo esse ao acento grave indicador de crase. Ocorre que à época era comum acentuar o artigo definido feminino para distinguilo da preposição, como facilmente se constata, por exemplo, nos escritos de José de Alencar. Trata-se, na verdade, de uma composição preciosa, que dispensa a preposição antes daquele substantivo. Esse mesmo uso do acento ocorre em pelo menos mais um passo.

Aúnica publicação do poema A um preso até aqui encontrada é aquela do Parnaso de Pereira da Silva, em cujo segundo volume aparece nas páginas 224 e seguinte. Não foi localizada informação sobre a motivação desse poema, bem como a data de escrita e se foi publicado em outro lugar além desse livro (o que provavelmente terá ocorrido). Foi corrigido o segundo verso da última estrofe - "Novos Gamas fazendo-te caminho" -, que no original traz novas em lugar de novos, que parece ser uma evidente gralha tipográfica. Anota-se, porém, que essa revisão de uma falha evidente se faz com bastante cautela, uma vez que o organizador dessa coletânea é comumente reconhecido como não muito rigoroso no seu trabalho e tentar corrgi-lo pode conduzir a erro sobre erro. Assim alguma outra incongruência foi deixada para que o próprio leitor faça seu juízo.

O primeiro soneto da coletânea - "Despido em praça pública, amarrado" - é aquele que, segundo Leal, foi provocado pelo supliciamento público de um escravo, quando o autor tinha treze anos e foi assim preservado, sem posteriores revisões. Não há notícia da sua publicação em vida do autor, aparentemente a primeira edição se deu no Pantheon maranhense; está reproduzido completo no livro $O$ negro na literatura brasileira, de Raymond Sayers (1958. p. 146-147). O soneto "Sai Minotauro..." fecha pelo verso "Desfalece, cai, urra, treme e morre!", que conforme a mesma fonte lhe serviu mote. Trata-se de verso da primeira estrofe da Lira 24 da segunda parte de Marília de Dirceu (Lira 91 na edição de Rodrigues Lapa), de Tomás Antônio Gonzaga, que começa pelo verso "Eu vou, Marília, vou brigar co’as feras!".

O soneto "Sempre a teu mando pronto obedecendo", por sua vez, foi dedicado ao General Jorge Manuel Rodrigues e está reproduzido no Esboço biográfico escrito por Faustino Xavier de Novaes e publicado no periódico literário O Futuro (ano I, v. XIII, p. 414-415, 15 de março de 1863). Esse artigo foi reproduzido na Revista do Instituto Histórico Geográfico e Etnográfico Brasileiro, sempre com a inserção do poema (tomo 30, p. 231, primeiro trimestre de 1867). Está reproduzido na antologia de Pereira da Silva e também na Castália brasileira (p. 246). O quarto verso desse soneto - "Da marcial trovoada o ruído 
horrendo" - é citação do inacreditável poema Málaca conquistada, do português Francisco de Sá de Meneses, publicado em Lisboa em 1634.

Segundo informa Leal, o soneto "Vejo-te, não me ilude a fantasia" foi dedicado a Rossini, de quem Odorico era amigo, e lhe foi enviado acompanhando um exemplar do Virgílio brasileiro. Até agora não se localizou nenhuma publicação do poema além daquela que consta do Pantheon. O soneto seguinte, Luís Napoleão, primeiro do Trio da Guerra da Itália, foi reproduzido, em versão inferior à de Leal, no livro Sonetos brasileiros, organizado por Laudelino Freire e publicado em 1913, sem informação da fonte. Aquele que se inicia pelo verso "Partis, adeus amigo, adeus, senhora" está datado "Rio, janeiro de 1846" e foi, segundo Henriques Leal, escrito em homenagem a um casal de amigos do poeta que partia para a Europa. Também dessa obra não se noticia outra publicação. Mas é quase certo que a maioria desses escritos tenha circulado nos jornais da época, onde é provável que ainda repousem outros escritos até agora não recolhidos em livro.

É importante frisar que a coletânea à frente não passou por uma edição crítica; não se dispõe de material que o permita. Trata-se de uma edição cuidadosa de material colhido quase todo de uma mesma fonte, por sua vez não muito confiável quanto ao rigor com que foi preparada. Buscou-se fazer o melhor trabalho possível com o material de que se dispunha, correndo-se os riscos inerentes a tal projeto. Em todos os poemas foi feita a adequada atualização ortográfica buscando sempre não interferir no texto. Assim, foram preservadas as maiúsculas iniciais dos versos e de algumas palavras, bem como a pontuação idiossincrática, escrupulosamente reproduzida, excessão feita ao caso do verso "Do rio que espontâneo se oferece", acima especificado.

Para concluir esta apresentação observa-se que a verdade é que, não obstante as palavras generosas de Sílvio Romero e José Veríssimo e os rasgados elogios de Antônio Henriques Leal (parcialmente repetidos por alguns outros maranhenses), Odorico Mendes vem sendo sistematicamente ignorado pelos historiadores da literatura brasileira e mesmo pela grande maioria das mais amplas antologias da nossa poesia. Dos fascículos de Januário da Cunha Barbosa, passando por Varnhagen e o seu Florilégio e chegando à atualidade, a sua ausência é, pode-se dizer, clamorosa. Mesmo aquelas coleções dedicadas exclusivamente aos períodos romântico e pré-romântico costumam contornar a sua produção. As diversas antologias organizadas por Manuel Bandeira o ignoram soberanamente, mesmo a mais que ampla Obras primas da lírica brasileira em sua segunda edição (1957), que reúne 146 (sic) poetas, não o arrola. O poeta antologista cita seu nome logo no parágrafo de abertura 
do prefácio da Antologia dos poetas brasileiros da fase romântica (1937) como parte da lista dos poetas estudados por Sílvio Romero na História da literatura brasileira. E só. O também extenso Panorama da poesia brasileira em seus seis volumes ignora sua produção, sendo nomeado por Cavalheiro na introdução do volume que acolhe o Romantismo, como um precursor. Também apenas isso. Observe-se que essas antologias acolhem muitos poetas que, não figurassem nelas, raramente seriam lembrados, não passando de nomes em listas em final de capítulos nos manuais de história da literatura. Mesmo seu conterrâneo Sotero dos Reis, no seu Curso de literatura brasileira e portuguesa (1868), que cita copiosamente seus poetas, não apresenta sequer um verso de lavra de Odorico Mendes, limitando-se a tratar da tradução da Eneida, de que cita dois pequenos trechos, totalizando 43 versos. O poeta seguinte no mesmo livro, Gonçalves Dias, tem centenas e centenas de versos transcritos, sendo inúmeros poemas (muitos deles longos) completos e incontáveis páginas d'Os Timbiras. Também a Antologia nacional de Fausto Barreto e Carlos de Laet (1913) ignora os poemas de Odorico, citando de sua escrita 66 versos do Virgílio brasileiro. O Novo Parnaso brasileiro, publicado depois de 1853 também não menciona nenhuma produção sua. $\mathrm{O}$ desconhecimento desses poucos poemas de lavra do tradutor dos clássicos é tão grande que José Veríssimo, que tão bem acolheu o poema À tarde, menciona-o na sua História da literatura brasileira como sendo a única peça de autoria de Odorico, merecedora de citação e leitura (1963. p. 189). Portanto, seja considerando a importância dada ao tradutor, seja a pouca luz lançada sobre o poeta, parecem as duas solicitar uma maior atenção à sua poesia, mais que justificando o empenho na divulgação dessa escassa produção, independentemente de critério estético ou juízo de valor. Dessa maneira, poderá o leitor, mais que guiar-se pelo que dizem críticos, historiadores ou antologistas, formar um juízo próprio a partir do contato direto com a poesia de Manuel Odorico Mendes. Melhor sistema não parece haver.

\section{REFERÊNCIAS BIBLIOGRÁFICAS}

BANDEIRA, Manuel. (org.). Obras primas da lírica brasileira. 2. ed. rev. e aum. São Paulo: Martins, 1957.

. (org.). Antologia dos poetas brasileiros da fase romântica. Rio de Janeiro: Imprensa Nacional, 1937.

BARRETO, Fausto; LAET, Carlos de. Antologia nacional. 6. ed. Rio de Janeiro: Francisco Alves, 1913. 
BRAGA, Gentil Homem de Almeida et al. (org.). Parnaso maranhense. São Luís: Typ. do Progresso, 1861.

CAMPOS, Haroldo. Metalinguagem e outras metas. 4. ed. rev. e ampl. São Paulo: Perspectiva, 1992.

CANDIDO, Antonio Formação da literatura brasileira. 11. ed. Rio de Janeiro: Ouro sobre Azul, 2007.

CARVALHO, Henrique Alves de. "Ao leitor". In: HOMERO. Iliada. Tradução de Odorico Mendes. Rio de Janeiro: Typographia Guttemberg, 1874. p. III-VIII.

CAVALHEIRO, Edgar. (org.). Panorama da poesia brasileira: v. II: o Romantismo. Rio de Janeiro: Civilização Brasileira, 1959.

FREIRE, Laudelino. (org.). Sonetos brasileiros: século XVII-XX. Rio de Janeiro: F. Briguiet, 1913.

LEAL, Antônio Henriques. Manuel Odorico Mendes. In: . Pantheon maranhense: ensaios biográficos dos maranhenses ilustres já falecidos. 4 v. Lisboa: Imprensa Nacional, 1873-1875. v. I, p. 1-99.

LISBOA, João Francisco. "Biographia do auctor escripta e publicada em 1862 por João Francisco Lisboa”. In: HOMERO. Iliada. Rio de Janeiro: Typographia Guttemberg, 1874. p. IX-XL.

LOPES, Hélio. A divisão das águas. São Paulo: Conselho Estadual de Artes e Ciências Humanas, 1978.

MEIRA, Olinto José. (org.). Castália brasileira: ou poesias seletas dos autores brasileiros, antigos e modernos. Tomo I. Recife: Typ. da Viuva Roma \& Filhos, 1850.

MENDES, Manuel Odorico. Opusculo acerca do Palmerim de Inglaterra e do seu autor no qual se prova haver sido a referida obra composta originalmente em portuguez. Lisboa: Typographia do Panorma, 1860. . À tarde. Minerva Brasiliense, Jornal de Ciências, Letras e Artes publicado por uma Associação de Literatos, Rio de Janeiro, v. I, n. 12, p. 367-368, 15 de abril de 1844.

MORAIS FILHO, Melo. Curso de Literatura brasileira. 4. ed. Rio de Janeiro: H. Garnier, 1902.

MORAIS FILHO, A. Melo. Parnaso brasileiro. 2 v. Rio de Janeiro: Garnier, 1885.

PARANHOS, Haroldo. História do Romantismo no Brasil. 2 v. Rio de Janeiro: Cultura Brasileira, 1937.

REIS, Francisco Sotero. Manuel Odorico Mendes. In: . Curso de literatura portuguesa e brasileira. 5 v. São Luís: s. ed. (Typ. de B. de Matos imprimiu), 1868. v. IV. p. 289307. 


$$
412 \text { - Remate de Males } 32.2
$$

RODRIGUES, Antônio Medina. Apresentação/Prefácio. In: HOMERO. Ilíada. 3. ed. São Paulo: Edusp, 200o. p. 15-18/19-54.

ROMERO, Sílvio. História da literatura brasileira. 5. ed. 5 tomos. Rio de Janeiro: José Olympio, 1953-1954.

SAYERS, Raymond S. O negro na literatura brasileira. Traduzido por Antônio Houaiss. Rio de Janeiro: O Cruzeiro, 1958.

SILVA, J. M. P. da. (João Manuel Pereira). Parnaso brazileiro. 2 v. Rio de Janeiro: Eduardo e Henrique Laemmert, 1843-1848.

VERÍSSIMO, José. História da literatura brasileira. 4. ed. Brasília: Ed. UNB, 1963.

WOLF, Ferdinand. Le Brésil littéraire: histoire de la littérature brésilienne suivie d'un choix de morceaux tirés des meilleurs auteurs brésiliens. Berlin: A. Asher \& Co. (Albert Cohn \& D. Collin), 1863. 


\title{
Oliveira- 413 \\ OUTROS POEMAS
}

Manuel Odorico Mendes

\begin{abstract}
À tarde
Que hora amável! Espiram os favônios;

Transmonta o Sol; o rio se espreguiça;

E a cinzenta alcatifa desdobrando

Pelas azuis diáfanas campinas,

$\mathrm{Na}$ carroça de chumbo assoma a tarde.

Salve, moça tão meiga e sossegada;

Salve, formosa virgem pudibunda,

Que insinuas co'os olhos doce afeto,

Não criminosa abrasadora chama.

Em ti repousa a triste humana prole

Do trabalhado dia, nem já lavra

Juiz severo a bárbara sentença,
\end{abstract}

Que há de a fraqueza conduzir ao túmulo.

Lasso o colono, mal avista ao longe

A irmã da noite, coa-lhe nos membros

Plácido alívio: posta a dura enxada,

Limpa o suor que em bagas vai caindo.

Que ventura! A mulher o espera ansiosa

Co'os filhinhos em braços: já deslembra

O homem dos campos a diurna lida;

Com entranhas de pai ledo abençoa

A progênie gentil que a olho pula.

Não vês como o fantasma do silêncio

Erra, e pára o bulício dos viventes?

Só quebra esta mudez o pastor simples,

Que, trazendo o rebanho dos pastios,

Co'a suspirosa flauta ameiga os bosques.

Feliz! que nunca o ruído dos banquetes

Do estrangeiro escutou, nem alta noite

Foi à porta bater de alheio alvergue.

Acha no humilde colmo os seus penates, Como acha o grande em soberbões palácios;

Ali também no ouvido lhe estremecem 
De mãe, de amigo os maviosos nomes;

Conviva dos festins da natureza, Vê prefazerem-se as funções mais altas:

O homem nascer, morrer, e deixar prantos.

Agora ia entre prados, após Laura,

$\mathrm{O}$ ardido vate magoando as cordas;

E a selvática virgem, recolhendo

A grave dor cristã, que a assoberbava

Do mancebo cedia à paixão nobre,

Grande e sublime, como os troncos do ermo...

Ai! mísera Atalá... mas rasga o fogo,

E o sino soa pelas brenhas broncas.

Tarde, serena e pura, que lembranças

Não nos vens despertar no seio d'alma?

Amiga terna, dize-me, onde colhes

O bálsamo que esparges nas feridas

Do coração? Que apenas dás rebate,

Cala-se a dor; só geras no imo peito

Mansa melancolia, qual ressumbra

Em quem sob os seus pés tem visto as flores

Irem murchando, e a treva do infortúnio

Ante os olhos medonha condensar-se.

Longe dos pátrios lares, quem não sente

Os arrebois da tarde contemplando

Um súbito alvoroço? Então pendíamos

Dos cantos arroubados que verteram

Propícios deuses nos maternos lábios;

E branda mão apercebia o berço

Em que tenros vagidos afagava

Infausto anúncio de vindouras penas.

Sobre o poial sentada a fiel serva Que vezes atentei chamando ao pouso A ave tão útil que arrebanha os filhos, E adeja e canta, e pressurosa acode!

Co'a turba de inocentes companheiros, Agora sobre a encosta da colina, A casta lua como mãe saudávamos, 
E suplicando que nos fosse amparo,

Em jubilosa grita o ar rompíamos.

Mas da puerícia o gênio prazenteiro Já transpôs a montanha; e com seus risos

Recentes gerações vai bafejando:

A quem ficou a angústia, que moderas,

Ó compassiva tarde. Olha-te o escravo,

Sopeia em si os agros pesadumes:

Ao som dos ferros o instrumento rude Tange, bem como em África adorada, Quando (tão livre!) o filho do deserto

Lá te aguardava; e o eco da floresta,

Da ave do gorjeio, o trépido regato,

Zunindo os ventos, murmurando as sombras, Tudo, em cadência harmônica, lhe rouba A alma em mágico sonho embevecida.

Não mais; ó Musa, basta; que da noite

Os pardos horizontes se tingiram,

E me pesa e carrega a escuridade.

$\mathrm{Oh}$ ! venha a feliz era que da pátria

Nessas fecundas, dilatadas veigas

Tu mais suave a lira me temperes:

Da singela Eponina acompanhado, Na escura gruta que nos cava o Tempo, Hei de ao vale ensinar canções melífluas:

Nos lindos olhos, nos mimosos beiços, Nos alvos pomos, no ademane altivo, Irei tomar as cores que retratem Da natureza os íntimos segredos:

Do ardor da esposa, do sorrir da filha;

Do rio, que espontâneo se oferece;

Da terra que dá fruto sem o arado;

Da árvore agreste, que na densa grenha Abriga da pendente tempestade, A sobreolhar aprenderei haveres. A fazer boa sombra ao peregrino, A dar quartel a errado viandante. Lá estendendo pelos livres ares Longas vistas, nas dobras do futuro Entreverei o derradeiro dia... 
416 - Remate de Males 32.2

Venha; que acha os despojos do homem justo.

Ó esperança, toma-me em teus braços;

Com a imagem da Pátria me consola. 


\section{Oliveira- 417 \\ O sonho}

O furacão da morte

Entra medonho os campos da existência,

Perdoa a secos troncos, Leva consigo florescentes plantas, Cuidados do colono esperançoso.

Sobre o meu leito pobre Se debruça a cruel, fita-me os olhos;

Um pérfido sorriso

Lhe torce os beiços pálidos... já vejo As mágoas, as saudades da partida,

Da pátria o doce ninho,

Da mãe (tão terna!) as lágrimas sentidas,

Dos irmãos, dos amigos,

O último adeus; e em Letes ensopado

O negro manto, que me cubra a campa!

Quão triste a final cena!

Mas o quadro da vida ainda é mais triste!

As breves alegrias

Num só ponto aparecem mal distintas, E sombream-lhe o fundo os infortúnios.

Que bens há cá na terra?

O crime estende o formidável cetro,

Raro fulge a virtude;

Em torno ao coração o prazer voa, A dor penetra, e vai sentar-se no âmago!

Eu, que em meus devaneios

Sonhei tanto com glórias e venturas,

Vi sempre derribadas

As esperanças; e o pungente alfange

Da desfortuna contra mim alçar-se;

No círculo afanoso

De meus juvenis anos nada tenho

Que agradeça ao destino. 
418 - Remate de Males 32.2

Da velhice os pesares me aguardavam!

Contente apararei o extremo corte. 


\section{Oliveira- 419 \\ $\mathrm{O}$ meu retiro}

Se Deus propício os votos me atendesse,

Certo não me daria cópia de ouro, Nem levantar nas orgulhosas praças

Egrégios torreões, alvos da inveja:

$\mathrm{O}$ tronco a que meu pai se recostava,

O sítio em que nasci, o pomar fresco

Onde a primeira vez o amor sorriu-me,

De tão longe me chamam, me convidam,

Que no pátrio regaço vá lançar-me.

Sem enxergar o fumo da cidade,

Sem lhe ouvir o estampido das borrascas,

Meus alvos dias gozarei inteiros

Sob a choça de palmas enramada.

Soltar-me anseio em vale solitário,

Não porque ódio professe à tão mesquinha

Progênie da mulher, mas à franqueza

Entrada veda trivial perfídia,

E ali me acerco de família estreme, Entro-a no peito, estreito-me com ela:

$\mathrm{E}$ o costume de amar guia à virtude.

O movedor eterno dos destinos

Largo espargiu no orbe os bens e os males;

Não lhe indago a razão: melhor me fora

Que o tempo, para quantos me são caros,

Se devolvesse perenal remanso;

Porém, se algum primeiro a campa cobre,

Se entra-lhe a casa a mísera desdita,

Para ornar meu retiro, o céu me outorgue

$\mathrm{O}$ órfão que à tosca sombra de meus tetos

Guarida encontre, e em vínculo sagrado,

Do pai, do amigo, a geração estenda.

Embora então me arroje no sepulcro

O fatal gume, não estranho, a fronte

Contente curvo, que me sobra em anos

Quem minhas cinzas regue, e a longos brados

Quase do férreo sono me desperte. 
Se ao homem desacompanha a mole inércia,

Farto banquete os gênios campesinos

Em frugíferos troncos lhe apresentam

Esquálida mulher aduladora,

Fel vertendo dos beiços a pobreza

Se lhe aproxima à porta, mas recua

Ao reluzir da carcomida enxada.

Enquanto aos pés dos grandes, o opulento, Aos pequenos soberbo, honras mendiga,

Da sôfrega ambição contra as lançadas

Ergue o agreste adamantino muro, Seguindo as trilhas da vivaz natura, Comparte o leito seu, limpo e fecundo, Donde a Têmis, a Ceres, a Mavorte Tem de manar alunos prestadios. Por guapas campanhias bocejantes

$\mathrm{O}$ insone regozijo não revoa Na pacífica aldeia; mas é grato

Observar o horizonte ao romper d'alva, Escutar o gemido da floresta, Beber o alento nos delgados ares, E em derredor da ovelha, em leves saltos, Ver o viçoso folgazão cordeiro.

Nos gostos de uma esposa? Dessas brenhas

Na filha atenta: as faces lhe avermelha

Frugal mesa, trabalho moderado, E, mais que tudo, a candidez e o pejo.

Boa mãe, amadora da simpleza,

Os filhos do seio pendurados

Não lhe murcham as graças; no semblante

Ledos sorrisos lhe derrama o júbilo, Quando pode afagar com mão mimosa A tão cruenta chaga do infortúnio. Oh! que íntimo alvoroço as fibras d'alma Lá me tem de abalar, se inesperado Eu avistasse no arvoredo próximo O meu querido Ernesto, que em demanda Do meu retiro plácido caminhe. Mal que eu tão doce nome balbucie 
Entalado em suspiros, a consorte Há de entre os braços apertar o amigo Que honrou minhas desgraças com seu pranto,

Do hóspede então, conforme à singeleza Tenho de preparar festim campestre Que o coração profundo lhe lateje. Assim que a luz aponte matutina As filhas mandarei, dessas florestas Ninfas louçãs, tecer uma capela, Chamar as companheiras do contorno Que, com suaves cantos e tangeres, Espalhem pelos ares a alegria.

Depois que dermos voltas ao deleitoso Breve jardim, na sobervada gruta Lhe mostrarei o túmulo paterno: Lá juntos versaremos no futuro, Grande, condigno assunto qu'em dous ânimos Amizade maior entranha e arreiga.

Debaixo de odorífera latada Altar de relvas hei de ter já prestes. Onde, enfeitado de gentis boninas, $\mathrm{O}$ quadro se coloque majestoso Da que deu na masmorra virgem leite, Fonte de vida ao já caduco velho,

Do filial amor exemplo nobre. Posta no amável hóspede a coroa, Aves pousadas nos arbóreos topes Os quebros naturais entremeando, Farão mais consonante o coro alpestre Quando o cântico rompa mavioso:

"Semelha o amigo nosso à ingênua moça: Ama e se acolhe ao pai, com tanto anelo, Como a seu ninho a roladora pomba. Feliz quem pode em braços dos penates, Com os olhos de morte carregados, Adormecer. Só deixa uma lembrança, E transita do mundo à etérea pátria. Por quem nos procriou afeto sumo 


$$
422 \text { - Remate de Males } 32.2
$$

Sentimos todos; mas prendeu-se no âmago

Do afável peregrino uma ternura

Que a querer nos ensina com mor brio, Semelha o amigo nosso à ingênua moça:

Ama e se acolhe ao pai, com tanto anelo, Como a seu ninho a roladora pomba."

É força entre os prazeres vir mágoa

Sentar-se. Deixarás nossa cabana, Meu bom amigo, e em lágrimas envoltos Árvore na colina plantaremos Que denote o saudoso apartamento. 


\section{A um preso}

Não algemas, não rostos desabridos,

Sequazes do infortúnio, te demoram

Dessa constância; que o varão condigno

Não se curva aos revezes.

Relâmpago, a puerícia esvaeceu-se;

E o coração estranhas que te cerque A nuvem da tristeza? Homem, não sabes

Esquivar-te à desgraça?

Ainda bem, que aguentas os embates

De enfurecidas vagas no regaço;

Da pátria, e o doce rir da irmã querida

N’alma te põe bonança.

Limpo de crimes, deixa que os tiranos As carniceiras garras dessedentem;

Lá lhes descabe ao temeroso brado, O suspenso cutelo.

Feliz! se a dizer chegas: "No meu peito

Despontaram as flexas do destino;"

Que então grato vestígio do passado

Tem de ameigar teus dias.

Campo te abre o verdor da mocidade A longas esperanças; ao conspecto Não recues da sorte, alarga a vista Ao rasgado futuro:

Olha, outra vez afugentando as trevas, A liberdade a bafejar teus lares;

A fronte inclina ao sacrossanto livro, Que luzeiros despede.

Olha, encetando o curso das grandezas Novos Gamas fazendo-te caminho A novos horizontes... Nem já ouves Chamar-te desditoso! 


\section{À S. M. o Sr. D. Pedro II no dia 2 de dezembro de 1839}

A quatorzena vez (Brasil, exulta!)

$\mathrm{O}$ alvo dia volveu que amigo gênio

Das mãos avaras arrancou do Tempo

Apenas reluzia sobre o horizonte, Um porvir despontou de paz e de ordem, A Independência verdadeira ergueu-se;

Nutou em seus projetos a Anarquia, Monstro infecundo, estragador do germe Da nacional grandeza, o influxo estranho Com riso amargo (hipócrita!), o saúda...

Filho da América, imortal carreira Traça, Príncipe Augusto; acaba a empresa Que infeliz Pai consolidar não pôde!

Herdeiro das virtudes que a mãe terna

Do peito no sacrário agasalhava, Sê com teu povo compassivo e brando. Já se aproxima a inesperada aurora Em que a Lei deste Império majestosa

Te convida a reger com braço hercúleo

O esperançoso americano cetro:

Então, sangue de Reis, não te deslumbre

O encanto do poder; ama, aprecia

Ser Brasileiro mais que ser Monarca.

Vejo o engano sagaz lançar-te a rede:

Ah! não te colha nas traidoras malhas!

Pela orla do vaso mel suave

Te ministra a Lisonja; o fel da angústia No fundo jaz. O intento que te anime Seja o firmar teu sólio sobre a larga, Do amor do povo, indestrutível base.

Rodeia os olhos pelo Império imenso: Que vês, que escutas, Príncipe sublime?

O almo terreno por colonos brada;

Pede o senhor dos rios que o navegues,

Ricas areias os demais te ofertam; Querem florestas em baixeis trocar-se, 
Que a fé mantida, o orgulho de estrangeiro,

Auriverde bandeira alçando abatam.

As belas-artes teu bafejo esperam,

$\mathrm{E}$ as musas te preparam mil grinaldas;

Por desenvolver sob teu mando

Arde veloz comércio, indústria sábia.

No tempo de paz tens de erigir-nos;

Neto de Afonsos brandirás a espada

Quando nos provocar a guerra insana;

Da honra zelador, dos bons costumes,

Serás o esteio da abalada crença!...

Quem, quem fará, Senhor, prodígios tantos?

Teu coração magnânimo, sustendo

A liberdade e o trono em laço eterno. 


\section{Despido em praça pública, amarrado}

Despido em praça pública, amarrado, Jaz o mísero escravo, delinquente: Negro gigante de ânimo inclemente Na mão tem o azorrague levantado.

A rir em torno, um bando encarniçado Ao verdugo promete um bom presente, Se com braço mais duro ao padecente Rasgando for o corpo ensanguentado.

Homens, não vos assiste a menor pena Dos sentidos seus ais, d'angústia sua? Rides, perversos, desta horrível cena?...

A sua obrigação, oh gente crua, Faz o reto juiz quando condena;

$\mathrm{Tu}$, deplorando o réu, cumpres a tua.

\section{Sai Minotauro com feroz bramido}

Sai Minotauro com feroz bramido Pelo intrincado labirinto horrendo, Os passos multiplica a Teseu vendo, Cego de fome em cólera acendido.

Sem perturbar-se o moço destemido, Mede o biforme atroz que vem correndo; Ariadne bela dentro n'alma tendo, Fica ainda mais que ele embravecido.

Que vai perdê-la, se na luta expira, Cheio de ânsia e de amor o heroi discorre, E esta lembrança mais lhe aumenta a ira:

Em fúria o Minotauro também corre, Preme-lhe o peito; o monstro a língua tira, Desfalece, cai, urra, treme e morrre! 


\section{Sempre a teu mando pronto obedecendo}

Sempre a teu mando pronto obedecendo Hei com meu sangue minha fé selado; Arrostei firme, ouvi desassombrado "Da marcial trovoada o ruído horrendo".

Hoje que à triste campa vou descendo

Queres-me ver, ó pátria, desonrado?

Dás-me este prêmio, quando nobre e ousado,

O último bocejar te voto e rendo!

Ah! bem que estou no inverno tenebroso, A minha espada é cortadora e forte,

O braço duro, o coração brioso!

Mas nem se me permite, indigna sorte! Que após meu filho intrépido e ditoso Alcance ao menos uma ilustre morte.

Partis, adeus amigo, adeus, senhora

Partis, adeus amigo, adeus, senhora,

Cá fico um seco tronco em soledade:

Tão sincera solícita amizade

Onde, oh! meu Deus, encontrarei agora?

Tantas finezas cada dia e hora!

Nas mágoas - terno pranto e piedade!...

O peito se me alaga de saudade,

O coração de dor suspira e chora.

Sei bem que ides gozar da culta França; Que de inimigos alcançando a palma, Cumpris vossos desejos e esperança:

Mas em mim a tristeza não se acalma;

Esta cruel ausência, esta mudança, Não é morte da vida, é morte d'alma! 


\section{Vejo-te, não me ilude a fantasia}

Vejo-te, não me ilude a fantasia, No Empíreo entrando, e pela mão saudoso Teu Bellini a guiar-te radioso. Ao Criador eterno da harmonia.

Nos anjos logo excitas alegria, No severo Moisés íntimo gozo, Tu que, sublime, terno e religioso, Nos inspiraste as mágoas de Maria.

Fitando a mãe, o Redentor exclama:

Este em sagrado músico se eleja, Pois a mulher cantou que Deus mais ama:

Ele os meus coros alternado reja; Ele despreze a vil terrena fama: Junto ao profeta-rei seu posto seja.

\section{O trio da guerra da Itália I: Luís Napoleão}

Medroso ante a misérrima Veneza, Depois que em Solferino triunfaste, A Itália, que acendeste, abandonaste; Infâmia eterna, pérfida baixeza!

A teu carro a Sardenha atada e presa, Com todo o continente a malquistaste, Áustria iludiste, Roma atraiçoaste, E tens a Europa toda na incerteza.

Mentes ao Papa, mentes à Inglaterra, Que já nos paroxismos da amizade, As queixas guarda e se aparelha à guerra. Desprezas, Bonaparte, a humanidade, Volves do Inferno, Luiz Onze, à terra... Oh ! poço de falácia e de maldade! 


\section{Oliveira- 429 \\ II: Vítório Emanuel}

Ir socorrer a nobre Itália escrava, Subtraí-la ao domínio do estrangeiro,

Era, por certo, egrégio cavaleiro, A digna empresa que te mais honrava:

Cálculo vil, condescendência ignara, Murchar-te veio os louros de guerreiro, Sucumbiste às astúcias do Embusteiro,

Que a príncipes e a povos enganara.

Empeçonhado o copo da vitória, Nos horizontes do porvir te cegas;

Ela caminha a cercear-te a glória;

Hoje ao Demônio vida e alma entregas;

Surdo aos pregões da velha ou fresca história,

O heróico amigo e teus avós renegas.

\section{III: Garibaldi}

Do Saboiano e Garibaldi ao grito A Itália ergueu-se: o herói ia adiante, O rei, com braço e intrepidez pujante, De árduos perigos ressurgia invicto.

Se um era baluarte do conflito,

O outro marchava -- estrela fulgurante;

A italiana mocidade ovante

Na pátria e nele tinha sempre o fito!

Mas ai! fiel nizeno malogrado!

Em Niza perdes quando havias ganho:

Que pesadumes te amontoa o fado!

Da honra em paga e de valor tamanho,

Vai ser da Itália o nome riscado,

Ou no país natal serás estranho! 
430 - Remate de Males 32.2

Aqui, junto da mãe, cortada em flor

Aqui, junto da mãe, cortada em flor, Jazem, caros irmãos, cinco pimpolhos;

Do pai vos mova o malogrado amor

-- Mágoa no coração, pranto na dor! 